Indonesian Journal of Medicine (2017), 2(3): 161-168

https://doi.org/10.26911/theijmed.2017.02.03.03

\title{
The Effectiveness of Adding Probiotic on Antimicrobial for Bacterial Vaginosis: A Systematic Review
}

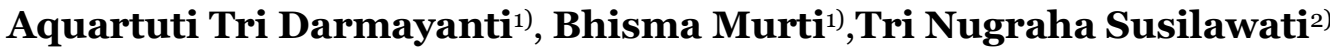 \\ 1)Masters Program in Public Health, Universitas Sebelas Maret \\ ${ }^{2)}$ Department of Microbiology, Faculty of Medicine, Universitas Sebelas Maret
}

\begin{abstract}
Background: Common antimicrobial regimens for treating bacterial vaginosis often cause recurrence and bacterial resistance. Previous studies have reported that a combination of antimicrobial and probiotic consisting of Lactobacillus spp. is an effective treatment for recurrent bacterial vaginosis. Lactobacillus plays an important role in vaginal health by replacing the pathogenic colonies in vagina. This study aimed to determine the effectiveness of adding probiotic to antimicrobial therapeutic for the prevention of bacterial vaginosis (BV) recurrence.

Subjects and Method: A systematic review was conducted by searching the following databases: PubMed, Science Direct, Web of Science, Springer Link and the Cochrane. The review included randomized controlled trials (RCTs) conducted in primary hospitals and private clinics. The Amsel criteria and Nugent score were used for diagnosis appraisal of bacterial vaginosis. were included in this systematic review consisting of the two types of bacterial vaginosis treatment. All pooled data analyses were based on random-effects models and intention to treat (ITT). Data were analyzed using Rev Man 5 software.

Results: The review included 5 RCTs involving 692 women on reproductive age underwent treatment of BV for 5 days or more. The studies showed that combination of probiotic and antimicrobial treatment reduced the risk of bacterial vaginosis recurrence a half time compared to antimicrobial treatment alone $(\mathrm{RR}=0.49 ; 95 \% \mathrm{CI}=0.17$ to 1.44$)$.
\end{abstract}

Conclusion: Adding probiotic to antimicrobial regimens is more effective than antimicrobial regimens alone for treating bacterial vaginosis recurrence.

Keywords: probiotic, antimicrobial, bacterial vaginosis recurrence, randomized controlled trial

\section{Correspondence:}

Aquartuti Tri Darmayanti. Masters Program in Public Health, Sebelas Maret University, Jl. Ir. Sutami 36 A, Surakarta 57126, Central Java. Email: tutiaquar@gmail.com.

Mobile: +6281329380114.

\begin{tabular}{l}
\hline BACKGROUND \\
\hline Vagina and ectocervix provide complex \\
habitat for several aerobic and anaerobic \\
microorganisms coexisting in a dynamic \\
balance for health (Mastromarino et al., \\
2013). In this environment, Lactobacillus \\
spp are the most dominant bacteria that \\
also plays an important role in the main- \\
tenance of the vaginal tract health (Alioua \\
et al., 2016). The imbalance of vaginal \\
microbiota including decreased amount of
\end{tabular}

Lactobacillus may cause vaginal inflammation.

There are millions of vaginitis annually, most are caused by bacterial vaginosis (BV) about (40\% to 50\%) (Vicariotto et al., 2014). However, the actual prevalence of $\mathrm{BV}$ is difficult to determine because many episodes are asymptomatic and occur during the menstrual cycle (Reid and Bocking, 2003).

Bacterial vaginosis is a polymicrobial syndrome involving condition that can 
change the composition of vaginal microorganisms. This syndrome is characterized by the decrease or absence of Lactobacilli, which cause the increase of the vaginal $\mathrm{pH}$ and the population of pathogenic bacteria such as Gardnerella vaginalis, Pretovella spp., Bacteroides sp., Mobiluncus spp. or genital mycoplasma (Silva et al., 2011). Bacterial vaginosis is associated with some adverse prognosis including 40\% increase in the risk of preterm birth (Stojanovi et al., 2012; Vicariotto et al, 2014), pelvic inflammatory disease (Haggerty et al., 2004), herpes, gonorrhea, and chlamydia (Marrazzo et al., 2007).

The treatment of BV using antimicrobial regimenssuch as oral metronidazole or intravaginal clindamycin have been reported to cause recurrences in approximately half of the cases. Moreover, the agents causing BV such as Gardnerella vaginalis and anaerobic bacteria show resistance to antimicrobial regimens (Beigi et al., 2004; Bradshaw et al., 2006).

Many studies have considered probiotics in addition to antimicrobial regimens (Martinez et al., 2009) because antimicrobials are not effective, causing recurrent infections and bacterial resistance. The probiotic containing Lactobacillus is frequently used for BV therapy since it can reduce intravaginal $\mathrm{pH}$, therefore providing a barrier effect against many pathogens as well as creating specific molecules such as hydrogen peroxide, extracellular proteins, and bacteriocin. These molecules kill and inhibit the growth of pathogenic bacteria (Mastromarino et al., 2013).

The types of Lactobacilli colonizing vagina include $L$. crisspatus, $L$. gasseri, $L$. iners, L. vaginalis, L. jensenii, and $L$. crispatus that can prevent urogenital infection by maintaining a low $\mathrm{pH}(<4.5)$ as well as producing bacteriostatic and bactericidal substances. Furthermore, colo- nizing probiotic could be engineered for facilitating pathogenic microbicide (Pendharkar et al., 2015).

The combination of probiotics and antimicrobial regimens or probiotics after antimicrobial regimens can restore Lactobacilli colonization after BV infection or after recurrence occurs in order to rebuild vaginal homeostasis. This can explain why women treated with probiotics have lower levels of long-term BV recurrence rate (Ling et al., 2013). This study aimed to determine the effectiveness of adding probiotic to antimicrobial regimens for the prevention of BV recurrence.

\section{SUBJECTS AND METHOD}

This review was conducted in accordance with the Preferred Reporting Items for Systematic Review and Meta-Analysis from the PRISMA Statement (Liberati et al., 2009). A systematic database searchwas performed from 1 to 15 September 2017. The databases included PubMed, Science Direct, Web of Science, Springer Link and the Cochrane Database. The keywords used were: probiotic AND metronidazole for bacterial vaginosis, probiotic AND antimicrobial AND randomized controlled trial, placebo dosage AND probiotic dosage AND bacterial vaginosis.

\section{Inclusion criteria}

The inclusion criteria were randomized controlled trials (RCTs), either single or double-blind RCTs using probiotic containing Lactobacillus spp. and antimicrobial regimens (e.g., metronidazole, tinidazole, and clindamycin), or antimicrobial and placebo. The subjects included were women on reproductive age and the therapy was given at least for 5 days. The studies were reviewed if the cases of lost to follow-up were less than 20\%. This review reported articles that published in English from 1994 until 2017. 


\section{Exclusion criteria}

Articles were excluded if the subjects are pregnant or post-menopause, intervention not relevant with the topic, the outcomes for RCTs were not bacterial vaginosis, and lack to follow-up.

\section{Primary outcome}

Nugent Score and Amsel criteria were used for diagnosing BV. The Nugent score criteria is based on the amount per point of view of airy morphotype organisms such as lactobacillus (given score 4 if not present in vaginal swab), Mobiluncus and Gardnerella vaginalis (given score 4 if there are $>30$ per point of view). A case with Nugent score of $7-10$ is diagnosed with BV (Bautista et al., 2016)

The Amsel criteria include (1) the acidity or $\mathrm{pH}$ of the vagina exceeds 4.7 , (2) vaginal discharge color are gray or white. (3) release a fish odor when whiff test is done $(10 \%$ potassium hydroxide mixed with vaginal discharge), and (4) there are clue cells on microscopy of the saline solution wet amount. Bacterial vaginosis is diagnosed when the patient presents with least 3 of those symptoms (Karim and Barakbah, 2016).

\section{Statistical analysis}

The RevMan 5 meta-analysis program was used in this review and the analysis included random effect and intention to treat (ITT).

\section{RESULTS}

A total of 348 articles were identified during initial search. After eliminating duplication and implementing the exclusion criteria, the remaining 81 RCTs were further analyzed. After careful examination of the full-text articles, finally, 5 articles were included for meta-analysis (Figure 1).

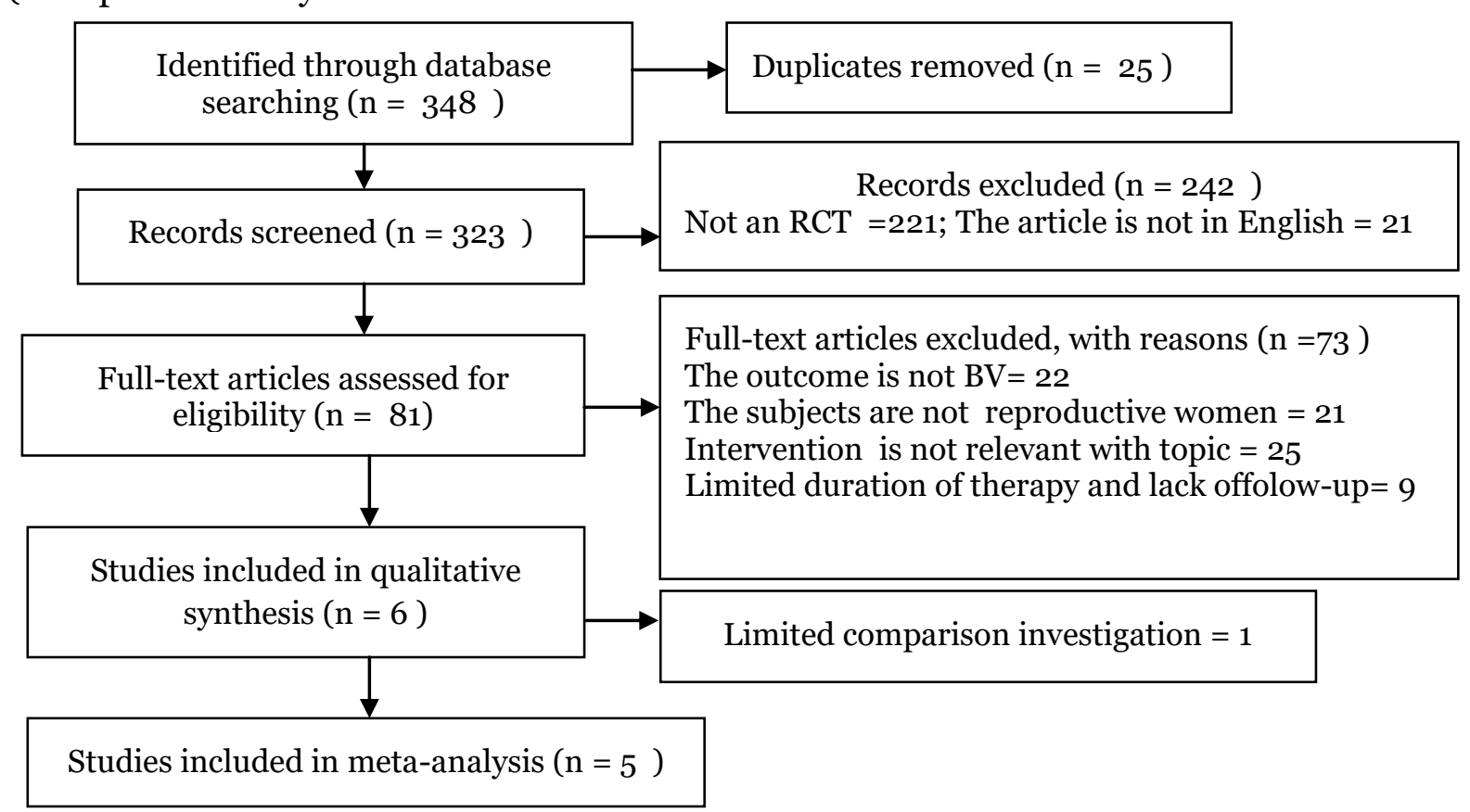

\section{Figure 1. Flow diagram of study selection}

The heterogeneity $\left(\mathrm{I}^{2}\right)$ of this metaanalysis is more than $50 \%$ so we calculate the relative risks (RRs) using random- effects model and intention to treat (ITT). (Akobeng, 2005). 
Darmayanti et al./ The Effectiveness of Adding Probiotic on Antimicrobial

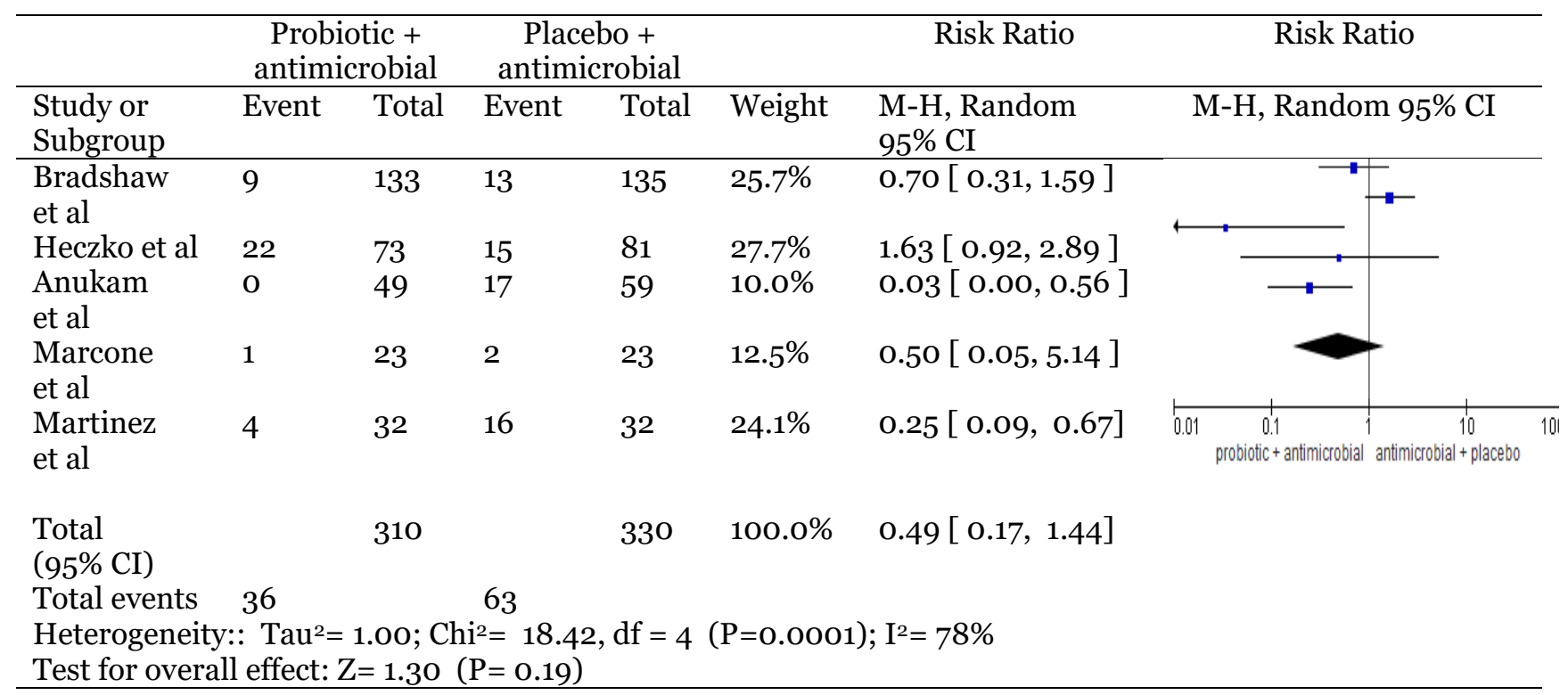

Figure 1. Forest plot for per protocol analysis between probiotic and antimicrobial vs antimicrobial vs placebo

\begin{tabular}{|c|c|c|c|c|c|c|c|}
\hline & \multicolumn{2}{|c|}{$\begin{array}{c}\text { Probiotic }+ \\
\text { antimicrobial } \\
\end{array}$} & \multicolumn{2}{|c|}{$\begin{array}{c}\text { Placebo }+ \\
\text { antimicrobial }\end{array}$} & \multicolumn{2}{|r|}{ Risk Ratio } & Risk Ratio \\
\hline $\begin{array}{l}\text { Study or } \\
\text { Subgroup }\end{array}$ & Event & Total & Event & Total & Weight & $\begin{array}{l}\text { M-H, Random } \\
\text { 95\% CI }\end{array}$ & $\begin{array}{l}\text { M-H, Random 95\% } \\
\text { CI }\end{array}$ \\
\hline $\begin{array}{l}\text { Bradshaw } \\
\text { et al }\end{array}$ & 9 & 150 & 13 & 150 & $25.4 \%$ & $0.69[0.31,1.57]$ & $\longrightarrow$ \\
\hline Heczko et al & 22 & 73 & 15 & 81 & $27.3 \%$ & $1.63[0.92,2.89]$ & $\therefore$ \\
\hline Anukam et al & o & 65 & 17 & 60 & $10.4 \%$ & $0.03[0.00,0.43]$ & 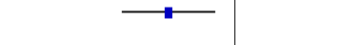 \\
\hline $\begin{array}{l}\text { Marcone } \\
\text { et al }\end{array}$ & 1 & 24 & 2 & 25 & $12.9 \%$ & $0.52[0.05,5.38]$ & \\
\hline $\begin{array}{l}\text { Martinez } \\
\text { et al }\end{array}$ & 4 & 32 & 16 & 32 & $24.0 \%$ & $0.25[0.09,0.67]$ & 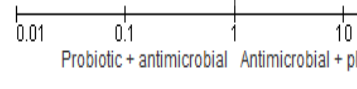 \\
\hline $\begin{array}{l}\text { Total }(95 \% \\
\text { CI) }\end{array}$ & & 344 & & 348 & $\begin{array}{l}100.0 \\
\%\end{array}$ & $0.47[0.15,1.43]$ & \\
\hline $\begin{array}{l}\text { Total events } \\
\text { Heterogeneity } \\
\text { Test for overal }\end{array}$ & $\begin{array}{l}36 \\
: \mathrm{Tau}^{2}= \\
\text { effect: }\end{array}$ & $\begin{array}{l}10 ; \mathrm{Cl} \\
1.33\end{array}$ & $\begin{aligned} & 63 \\
= & 19.73 \\
= & 0.19)\end{aligned}$ & . & $=0.00$ & $\mathrm{I}^{2}=80 \%$ & \\
\hline
\end{tabular}

Figure 2. Forest plot with ITT

1. Per-protocol analysis

The first analysis is for comparing the combination therapy ofprobiotic and antimicrobials such as metronidazole, $2 \%$ clindamycin or $2 \mathrm{~g}$ tinidazole with the combination of antimicrobials and placebo. It shows that the combination of probiotic and antimicrobial therapy prevents the occurrence of bacterial vaginosis 0.49 although it is not statistically significant $(\mathrm{RR}=0.49 ; 95 \% \mathrm{CI}=0.17$ to 1.44$)$.

2. Intention to treat (ITT) analysis

The ITT analysis wasperformedto prevent bias in RCTs. The result of the analysis shows there is no statistically significant difference in the outcomes of the combination of probiotic and antimicrobials vs antimicrobials and placebo in treating 
$\mathrm{BV} \quad(\mathrm{RR}=0.47 ; 95 \% \mathrm{CI}=0.15$ to 1.43$)$

protocol analysis.

which is similar to the results of per-

Table 1. Summary of included studies evaluating probiotic and antimicrobial vs antimicrobial and placebo

\begin{tabular}{|c|c|c|c|c|c|c|c|}
\hline $\begin{array}{l}\text { Author and } \\
\text { Year }\end{array}$ & Setting & $\begin{array}{l}\text { Total } \\
\text { follow- } \\
\text { up } \\
\text { Subjects }\end{array}$ & $\begin{array}{l}\text { Age } \\
\text { range }\end{array}$ & $\begin{array}{l}\text { Inclusion } \\
\text { Criteria }\end{array}$ & $\begin{array}{l}\text { Therapy } \\
\text { I: Intervention } \\
\text { C: comparison }\end{array}$ & $\begin{array}{l}\text { Route and } \\
\text { dosage }\end{array}$ & $\begin{array}{l}\text { Follow- } \\
\text { Up (days) }\end{array}$ \\
\hline $\begin{array}{l}\text { Bradshaw } \\
\text { et al., } 2012\end{array}$ & $\begin{array}{l}\text { Melbourn } \\
\text { e Sexual } \\
\text { Health } \\
\text { Centre } \\
\text { (MSHC) }\end{array}$ & 268 & $18-50$ & $\begin{array}{l}\text { females } \\
\text { with } \\
\text { symptoms } \\
\text { of BV }\end{array}$ & $\begin{array}{l}\text { I:L. acidophilus } 10^{7} \\
\text { CFU and } 400 \mathrm{mg} \mathrm{l} \\
\text { metronidazole } \\
\text { C: } 400 \mathrm{mg} \\
\text { Metronidazole and } \\
\text { Placebo }\end{array}$ & $\begin{array}{l}\text { Per Oral } \\
\text { twice } \\
\text { Daily }\end{array}$ & 180 \\
\hline $\begin{array}{l}\text { Heczko et } \\
\text { al., } 2015\end{array}$ & $\begin{array}{l}\text { Nine } \\
\text { private } \\
\text { outpatien } \\
\mathrm{t} \\
\text { gynecolog } \\
\text { ical clinics } \\
\text { in Poland }\end{array}$ & 154 & $18-50$ & $\begin{array}{l}\text { Menstrua } \\
\text { ted } \\
\text { regularly } \\
\text { and had } \\
\text { histories } \\
\text { of } \\
\text { recurrent } \\
\text { BV. }\end{array}$ & $\begin{array}{l}\text { I: : } 500 \text { mg } \\
\text { metronidazole and } \\
\text { proVag (L. } \\
\text { fermentum } 57 \mathrm{~A}, \mathrm{~L} . \\
\text { plantarum } 57 \mathrm{~B} \text {, and } \\
\text { L.gasseri } 57 \mathrm{C} \text { ) } \\
\text { C: } 500 \text { mg } \\
\text { metronidazole and } \\
\text { plasebo }\end{array}$ & $\begin{array}{l}\text { Per Oral } \\
\text { once daily }\end{array}$ & $\begin{array}{l}\text { Visit II: } \\
14 \\
\text { Visit III- } \\
\text { IV: 30 } \\
\text { (10 days } \\
\text { until } 3 \\
\text { months) }\end{array}$ \\
\hline $\begin{array}{l}\text { Anukam et } \\
\text { al., } 2006\end{array}$ & $\begin{array}{l}\text { Benin } \\
\text { City } \\
\text { metropol- } \\
\text { is }\end{array}$ & 108 & $18-44$ & $\begin{array}{l}\text { Having } \\
\text { symptoms } \\
\text { and signs } \\
\text { of BV }\end{array}$ & $\begin{array}{l}\text { I: } 500 \text { mg } \\
\text { metronidazole and } \\
\text { L. Rhamnosus GR-1 } \\
10^{9} \mathrm{CFU} \text { and L. } \\
\text { Reuteri RC- } \\
1410^{9} \mathrm{CFU} \\
\text { C: } 500 \mathrm{mg} \\
\text { metronidazole and } \\
\text { Placebo }\end{array}$ & $\begin{array}{l}\text { Per Oral } \\
\text { twice } \\
\text { daily }\end{array}$ & 30 \\
\hline $\begin{array}{l}\text { Marcone et } \\
\text { al., } 2010\end{array}$ & $\begin{array}{l}\text { Departm- } \\
\text { ent of } \\
\text { ObsGyn, } \\
\text { Sapienza } \\
\text { Universit } \\
\text { y, Rome }\end{array}$ & 46 & $18-45$ & $\begin{array}{l}\text { In the } \\
\text { diagnosis } \\
\text { of } \\
\text { bacterial } \\
\text { vaginosis }\end{array}$ & $\begin{array}{l}\text { I: L. rhamnosus } \\
>4000 \mathrm{CFU} \text { and } \\
500 \mathrm{mg} \\
\text { metronidazole } \\
\text { C: } 500 \mathrm{mg} \\
\text { metronidazole }\end{array}$ & $\begin{array}{l}\text { Per Oral } \\
\text { once daily }\end{array}$ & 7 \\
\hline $\begin{array}{l}\text { (Martinez } \\
\text { et al., } \\
\text { 2009) }\end{array}$ & $\begin{array}{l}\text { Universi- } \\
\text { dade de } \\
\text { Sao Paulo } \\
\text { (USP) }\end{array}$ & 64 & $16-51$ & $\begin{array}{l}\text { In the } \\
\text { diagnosis } \\
\text { of } \\
\text { bacterial } \\
\text { vaginosis }\end{array}$ & $\begin{array}{l}\text { I: L. rhamnosus, } \\
\text { L.reuteri } 108 \text { CFU, } \\
\text { and } 2 \text { g tinidazole } \\
\text { C: Placebo and } 2 \mathrm{~g} \\
\text { tinidazole }\end{array}$ & $\begin{array}{l}\text { Per Oral } \\
\text { once daily }\end{array}$ & 28 \\
\hline
\end{tabular}

\section{DISCUSSION}

Marcone et al. (2010) reported that metronidazole treatment alone without complementary Lactobacillus inhibited flora vaginal restoration. This resulted in BV relapse after 6 months of therapy and the recurrence rate increases over time. For this reason, it is possible that local administration of Lactobacillus spp. could be a useful complementary regimen in the manage- ment of recurrent urinary tract infections, especially those associated with BV.

Lactobacillus rhamnosus exhibits adhesion properties on urogenital epithelium, competing with other microorganisms. This bacteria also produce a number of factors that inhibit the growth of pathogenic bacteria in lower reproductive tract (Falagas et al. 2007). 
Lactobacillus reuteri $\mathrm{RC}-14$ could displace Gardnerella vaginalis biofilms in vitro. This was not due to $\mathrm{pH}$ which remained between 4.7 and 5.1 in all experiments.

Lactobacillus crispatus 33820 produces high amounts of hydrogen peroxide ( $\left.\mathrm{H}_{2} \mathrm{O}_{2}\right)$. The effects of $\mathrm{H}_{2} \mathrm{O}_{2}$ will depend on the oxidizing ability of the bacterial cell. Hydrogen peroxide works alongside other organic acids to overcome pathogenic bacteria (Martinez et al., 2009).

However, it is important to note that the results of probiotic therapy in BV depends on its dosage. The previous studies shown that $2 \times 10^{8} \mathrm{CFU}$ of L. rhamnosus or L. fermentumtwice daily gives a better therapeutic effect than $1 \times 10^{8} \mathrm{CFU}$ once daily (Reid , 2001; Bohbot and Cardot, 2012).

We suggest to give probiotic according to thepatient condition as the normal flora in vagina is influenced by the age and hormonal state. This study excludes pre and post menopausal women because the $\mathrm{BV}$ incidence in women during this period increase as a result of decreased estrogen hormone that has been associated with a decrease in the amount of Lactobacillus in the vagina (Cribby et al., 2008).

\section{CONFLICT OF INTEREST}

None declared.

\section{REFERENCES}

$\overline{\text { Akobeng AK (2005). Understanding syste- }}$ matic reviews and meta-analysis. Archives of Disease in Childhood, 90 (8): $845-848$.

Alioua S, Abdi A, Fhoula I, Bringel F, Boudabous A, Ouzari IH (2016). Diversity of vaginal lactic acid bacterial microbiota in 15 Algerian pregnant women with and without bacterial vaginosis by using culture inde- pendent method. Journal of Clinical and Diagnostic Research, 10(9)

Anukam K, Osazuwa E, Ahonkhai I, Ngwu M, Osemene G, Bruce AW, Reid G (2006). Augmentation of antimicrobial metronidazole therapy of bacterial vaginosis with oral probiotic Lactobacillus rhamnosus GR-1 and Lactobacillus reuteri RC-14: randomized, double-blind, placebo controlled trial.Microbes and Infection, 8(6): 1450-1454.

Bautista CT, Wurapa E, Sateren WB, Morris S, Hollingswprth B, Sanchez JL (2016). Bacterial vaginosis: a synthesis of the literature on etiology, prevalence, risk factors, and relationship with chlamydia and gonorrhea infections.Military Medical Research, 3 (1): 4.

Beigi R, Autin M, Meyn L, Kroohn M, Hiller $\mathrm{S}$, et al. (2004). Antimicrobial resistance associated with the treatment of bacterial vaginosis.American Journal of Obstetrics and Gynecology, 191(4): 1124-1129.

Bohbot JM, Cardot JM (2012). Vaginal impact of the oral administration of total freeze-dried culture of LCR 35 in healthy women. Infectious Diseases in Obstetrics and Gynecology.

Bradshaw CS, Morton AN, Hocking J, Garland SM, Morris MB, Lona MM, Horvat LB, et al. (2006). High Recurrence Rates of Bacterial Vaginosis over the Course of 12 Months after Oral Metronidazole Therapy and Factors Associated with Recurrence.The Journal of Infectious Diseases, 193 (11): 1478-1486.

Bradshaw CS, Pirotta M, Guingand DD, Hocking JS, MMorton AN, Garland SM, Fehler G (2012). Efficacy of oral metronidazole with vaginal clindamycin or vaginal probiotic for bacterial 
vaginosis: Randomised placebocontrolled double-blind trial. PLoS ONE, 7(4): 1-10.

Cribby S, Taylor M, Reid G (2008). Vaginal microbiota and the use of probiotics. interdisciplinary perspectives on infectious diseases: 1-9.

Falagas ME, Betsi GI, Athanasiou S (2007). Probiotics for the treatment of women with bacterial vaginosis. Clinical Microbiology and Infection. European Society of Clinical Infectious Diseases, 13(7): 657-664.

Haggerty CL, Hiller S, Bass D, Ness R (2004). Bacterial vaginosis and anaerobic bacteria are associated with endometritis. Clinical infectious diseases: an official publication of the Infectious Diseases Society of America. $39(7)$.

Heczko PB, Tomusiak A, Adaski P, Jakimiuk AJ, Stefański G, Cichońska AM, Szczurek MS, et al. (2015). Supplementation of standard antibiotic therapy with oral probiotics for bacterial vaginosis and aerobic vaginitis: a randomised, double-blind, placebocontrolled trial. BMC Women's Health, 15(1): 115 .

Karim A, Barakbah J (2016). Studi retrospektif: vaginosis bakterial (retrospective study: bacterial vaginosis). 56.

Krauss-SilvaL, Moreira MEL, Alves MB, Braga A, Caacho KG, Batista MRR, Horta AA, et al. (2011). A randomised controlled trial of probiotics for the prevention of spontaneous preterm delivery associated with bacterial vaginosis: preliminary results. Trials. BioMed Central Ltd, 12(1): 239.

Liberati A, Altman DG, Tetzlaff J, Mulrow C, Gøtzsche PC, John PA, Clarke M, et al. (2009). The PRISMA statement for reporting systematic reviews and meta-analyses of studies that evaluate healthcare interventions: explanation and elaboration.Bmj, 339: b270ob2700.

Ling Z, Liu X, Chen W, Luo Y, Yuan L, Xia $\mathrm{Y}$, Nelson KE, et al. (2013). The restoration of the vaginal microbiota after treatment for bacterial vaginosis with Metronidazole or probiotics. Microbial Ecology, 65(3): 773-780.

Marcone V, Rocca G, Lichtner M, Calzolari $\mathrm{E}$, et al. (2010). Long-term vaginal administration of Lactobacillus rhamnosus as a complementary approach to management of bacterial vaginosis. International Journal of Gynecology and Obstetrics. International Federation of Gynecology and Obstetrics, 110(3): 223-226.

Marrazzo JM, Martin DH (2007). Management of women with cervicitis. Clinical infectious diseases: an official publication of the Infectious Diseases Society of America, pp. S102-S110.

Martinez RCR, Silvio A, Patta MC, Quintaa SM, Gomes BC, Martinis ECP, et al. (2009). Improved cure of bacterial vaginosis with single dose of tinidazole (2 g), Lactobacillus rhamnosus GR-1, and Lactobacillus reuteri RC14: a randomized, double-blind, placebo-controlled trial. Canadian Journal of Microbiology, 55(2): 133-138.

Mastromarino P, Vitali B, Mosca L (2013). Bacterial vaginosis: a review on clinical trials with probiotics. The new microbiologica, 36: 229-38.

Pendharkar S, Brandsborg E, Hammarström L, Marcott H, Larsson PG, et al. (2015). Vaginal colonisation by probiotic lactobacilli and clinical outcome in women conventionally treated for bacterial vaginosis and yeast infection. BMC Infectious Diseases. BMC Infectious Diseases, 15(1): 255. 
Reid G, Beuerman D, Heinemann C, Bruce AW, et al. (2001). Probiotic lactobacillus dose required to restore and maintain a normal vaginal flora. FEMS Immunology and Medical Microbiology, 32(1): 37-41.

Stojanović N, Plećaš D, Plešinac S (2012). Normal vaginal flora, disorders and application of probiotics in pregnancy. Archives of Gynecology and Obste- trics, 286(2): 325-332.

Vicariotto F, Mogna L, Piano MD (2014). Effectiveness of the two microorganisms lactobacillus fermentum lf15 and lactobacillus plantarum lpo1, formulated in slow-release vaginal tablets, in women affected by bacterial vaginosis. Journal of Clinical Gastroenterology, S106-S112. 